\title{
MORPHOLOGICAL CHARACTERISTICS OF FEMALE STUDENTS OF PHYSICAL EDUCATION COMPARED TO STUDENTS OF OTHER SUBJECTS AT THE FACULTY OF PHYSICAL EDUCATION AND SPORT IN BIAŁA PODLASKA
}

\author{
AGNIESZKA WASILUK ${ }^{1}$, JERZY SACZUK ${ }^{1}$, JAN CZECZELEWSKI ${ }^{2}$, \\ BARBARA DŁUGOEĘCKA ${ }^{3}$, EWA CZECZELEWSKA ${ }^{4}$ \\ The Josef Pilsudski University of Physical Education in Warsaw, \\ Faculty of Physical Education and Sport in Biała Podlaska, \\ Department of Anthropology and Anthropomotorics ${ }^{1}$, Department of Biology and Anatomy ${ }^{2}$, \\ Department of Physiology and Biochemistry ${ }^{3}$ \\ ${ }^{4}$ Collegium Mazovia Innovative Higher Shool in Siedlce, Faculty of Health Sciences
}
Mailing address: Agnieszka Wasiluk, Faculty of Physical Education and Sport, Department of Anthropology and Anthropomotorics, 2 Akademicka Street, 21-500 Biała Podlaska, tel.: +48 83 3428741, fax: +48 83 3428800, e-mail: agnieszka.wasiluk@awf-bp.edu.pl

\begin{abstract}
Introduction. TIn a situation characterized by a low birth rate and a highly competitive education market, increasing attention is currently being paid not only to students' level of education, but also to their competencies and predisposition. Consequently, the purpose of this study is to analyze differences in morphological features among physical education students as compared with students of other subjects at the Faculty of Physical Education and Sport (WWFiS) in Biała Podlaska. Material and methods. This study is based on anthropometric data from 165 first-year female students at WWFiS in Biała Podlaska. Analysis was conducted on a selection of students divided into groups based on their study profile. Using the technique developed by Martin and Saller, measurements were taken of the anthropometric features required to determine BMI and WHR indexes and to estimate body tissue composition. The following were used to characterize the collected variables: sample size (n) arithmetic mean $(\bar{x})$ and standard deviation (SD). Differences among the groups with regard to the features being measured were assessed using ANOVA variation analysis and NIR testing. Results. The study did not confirm reports from other authors concerning analysis of connections between bodily structure and education profile. Thus, it should be concluded that a student's physique plays only a small role in their being selected to study physical education. Conclusions. The differences noted between the groups should rather be interpreted as owing to environmental differences in the lifestyles of the girls in question, rather than to recruitment procedures and, by extension, education profile.
\end{abstract}

Key words: students, physical education, BMI, WHR, body composition

\section{Introduction}

The literature on the somatic characteristics of college students, athletes and members of various professions, indicates close similarities in morphological characteristics among practitioners of the same professions, players of the same sports and students of the same subject $[1,2,3]$. The differences in somatic characteristics observed among college students were primarily connected with the qualification examination process. Students of the Academy of Physical Education represent a twofold selection from the general population. First, due to their decision to attend college. Second, due to their high level of physical fitness. As a result, the morphological parameters of students at AWF are different from those of students at other schools [4]. More and more studies have questioned the validity of this claim [5] and higher education has ceased to be viewed as a privilege. Today, almost everyone has access to higher education. Data from the Central Statistical Office for the academic years 1990/1991 and 2011/2012 indicates that the number of students at all types of institutions of higher learning has increased more than fourfold [6]. The rapid increase in the number of both colleges and students observed in the last decade of the $20^{\text {th }}$ century has clearly diminished in recent years. This is connected with the constantly decreasing number of people ages 19-24 [6]. In a situation characterized by a low birth rate and a highly competitive education market, increasing attention is currently being paid not only to students' level of education, but also to their competencies and predisposition [7]. At WWFiS in Biała Podlaska, students pursue five different majors. These are: physical education, sports, tourism and recreation, physical therapy and cosmetology. Candidates for the first two majors listed above are required to take a physical fitness exam involving: Three of the following athletic disciplines (candidate's choice): swimming, light athletics, gymnastics, team sports. Furthermore, the recruitment process for all majors awards points for A-level exam results. However, due to the low number of candidates in 2011, only the physical therapy major required that students attain a position on the ranking list. All remaining ma- 
jors accepted every candidate who expressed interest in studying at the school. In light of the above, the purpose of this study is to analyze differences in morphological features among physical education students at WWFiS in Biała Podlaska.

\section{Material and methods}

This study is based on anthropometric data from 165 firstyear female students at WWFiS in Biała Podlaska collected within the scope of the statuary activities of AWF Warsaw no. 172. The study was conducted in May 2012. Analysis was conducted of a selection of students divided into groups based on the profile of their major. Results obtained for students of sports and physical education were presented jointly. This decision was dictated by the low number of female students in the first of the two majors and by the specific selection criteria for that major, as well as by the educational program itself. Detailed data on the number of students who qualified for the individual groups is presented in Table 1.

Anthropomorphic measurements were taken using the technique developed by Martin and Saller [8]. Measurements were taken of height and body weight, waistline and hipline, lower leg circumference, elbow and knee width, biceps skinfold, triceps skinfold, chest skinfold, shoulder blade skinfold, hip skinfold, abdominal skinfold and lower leg skinfold. These direct measurements were then used to calculate the relative body mass index (BMI) [9] and to estimate body tissue composition [10]. Moreover, an organism's obesity level was determined based on the sum of three skinfolds - under the shoulder blade, over the triceps and on the abdomen - on the percentage of fatty tissue in the total body mass (F\%, Fkg) and the lean body mass (TA\%, TAkg). Calculations were also made of the waist to hip ratio (WHR), which indicates the type of body fat distribution [11].

The study was conducted in accordance with the principles of the Declaration of Helsinki and were accepted by the Parliamentary Ethics Committee at AWF Warsaw.

The collected results were subjected to statistical analysis. The following types of descriptive statistics were used to characterize the variables: sample size (n) arithmetic mean $(\bar{x})$ and standard deviation (SD). Differences among the groups with regard to the features being measured were assessed using ANOVA variation analysis and NIR testing. In graphically representing these differences, the average results for female students of Tourism and Recreation, Physical Therapy and Cosmetology were normalized based on an arithmetic mean and 1 standard deviation from students of Physical Education (Fig. 1).

\section{Results}

Analysis of the results revealed only minor differences in morphological features and relevant indexes among female students at WWFiS in Biała Podlaska, thus confirming a similar level of somatic development (Tab. 1-2, Fig. 1). Students of physical therapy were on average taller than students of physical education, a fact reflected in their higher BMI levels. Furthermore, they had larger waistlines, hiplines and arm and leg circumferences and broader elbow and knee widths. They also exhibited higher levels of obesity, although statistically significant differences between the groups were noted only for the lower leg skinfold index.
Table 1. Morphological characteristics of female students at WWFiS in Biała Podlaska

\begin{tabular}{|l|c|c|c|c|c|c|c|c|}
\hline & \multicolumn{2}{|c|}{$\begin{array}{c}\text { Physical } \\
\text { Education } \\
\text { and Sport (I) } \\
\text { n 48 }\end{array}$} & $\begin{array}{c}\text { Physical } \\
\text { Therapy (II) } \\
\text { n } 40\end{array}$ & $\begin{array}{c}\text { Tourism and } \\
\text { Recreation } \\
\text { (III) } \\
\text { n 25 }\end{array}$ & $\begin{array}{c}\text { Cosmetology } \\
\text { (IV) } \\
\text { n 52 }\end{array}$ \\
\hline & x & SD & x & SD & x & SD & x & SD \\
\hline Height & 166.76 & 5.46 & 168.38 & 5.63 & 165.55 & 6.35 & 165.96 & 6.04 \\
\hline Mass & 61.67 & 9.19 & 61.59 & 8.45 & 55.56 & 7.02 & 58.58 & 10.49 \\
\hline BMI & 21.32 & 4.84 & 21.72 & 2.67 & 20.16 & 1.81 & 21.20 & 3.09 \\
\hline Waistline & 69.39 & 6.11 & 69.95 & 6.95 & 68.76 & 5.73 & 70.99 & 8.43 \\
\hline Hipline & 95.30 & 5.42 & 97.02 & 6.95 & 93.42 & 5.58 & 95.89 & 7.11 \\
\hline WHR & 0.73 & 0.04 & 0.72 & 0.06 & 0.74 & 0.05 & 0.74 & 0.06 \\
\hline Arm circumference & 27.61 & 2.49 & 28.14 & 3.10 & 26.04 & 2.47 & 27.72 & 10.24 \\
\hline Lower leg circumference & 35.40 & 4.04 & 35.48 & 5.24 & 34.04 & 2.47 & 35.06 & 3.23 \\
\hline Elbow base width & 6.06 & 0.40 & 6.20 & 0.63 & 6.03 & 0.31 & 5.99 & 0.37 \\
\hline Knee base width & 8.53 & 0.60 & 8.82 & 0.57 & 8.71 & 0.76 & 8.87 & 0.55 \\
\hline Biceps skinfold & 6.97 & 2.18 & 8.21 & 3.13 & 8.40 & 2.81 & 7.85 & 3.03 \\
\hline Triceps skinfold & 15.68 & 4.43 & 17.20 & 4.61 & 14.05 & 3.64 & 14.97 & 4.36 \\
\hline Chest skinfold & 9.10 & 3.26 & 9.09 & 3.27 & 9.99 & 3.34 & 9.71 & 4.75 \\
\hline Elbow skinfold & 13.62 & 4.77 & 13.17 & 4.66 & 12.71 & 3.93 & 13.86 & 6.51 \\
\hline Shoulder blade skinfold & 18.59 & 5.03 & 19.23 & 7.48 & 17.31 & 4.82 & 18.84 & 6.90 \\
\hline Stomach skinfold & 16.39 & 4.56 & 17.55 & 6.11 & 16.49 & 4.28 & 17.41 & 6.12 \\
\hline Lower leg skinfold & 10.63 & 3.09 & 13.16 & 4.38 & 11.84 & 3.32 & 13.16 & 3.78 \\
\hline Total of 3 folds & 47.89 & 11.60 & 49.60 & 14.89 & 44.07 & 9.61 & 47.67 & 15.34 \\
\hline F\% & 24.48 & 4.07 & 25.02 & 4.17 & 23.26 & 4.04 & 23.84 & 4.24 \\
\hline TA\% & 75.52 & 4.07 & 74.98 & 4.17 & 76.74 & 4.04 & 76.16 & 4.24 \\
\hline Fkg & 15.30 & 4.20 & 15.69 & 4.51 & 13.07 & 3.43 & 14.25 & 4.67 \\
\hline TAkg & 46.36 & 5.95 & 45.89 & 4.42 & 42.49 & 4.45 & 44.32 & 6.54 \\
\hline & & & & & & \\
\hline
\end{tabular}

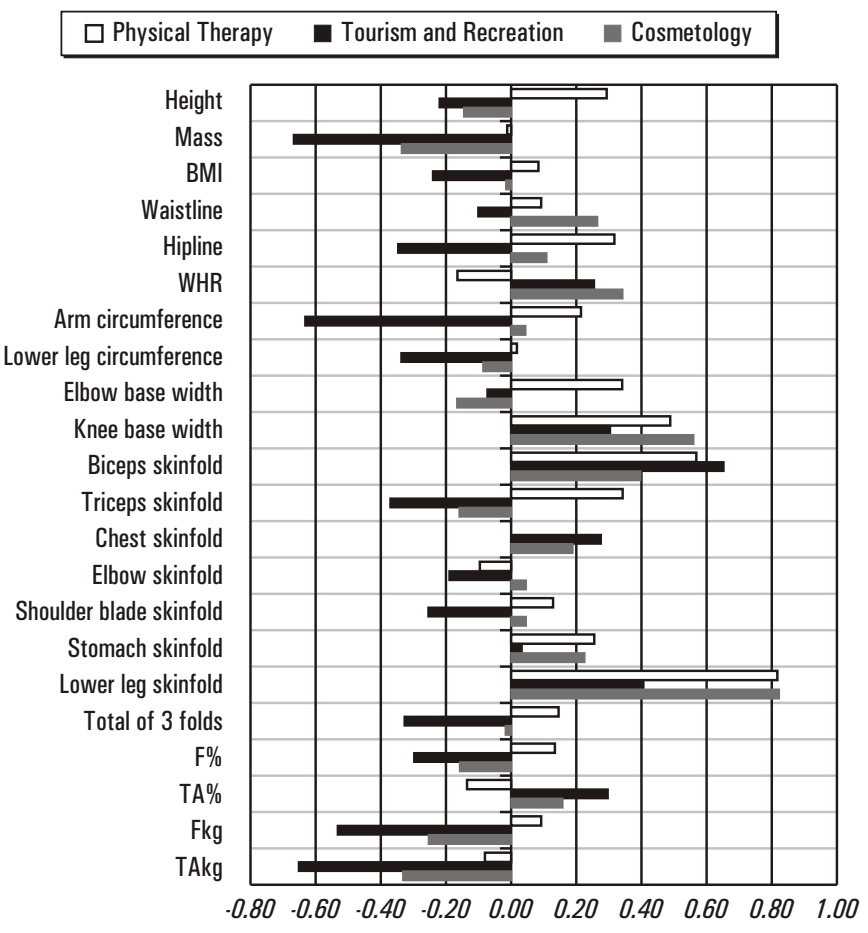

Figure 1. Morphological profile of female students involved in the study as compared to female students of physical education 
Table 2. One-way analysis of variance calculated for dependency among study groups

\begin{tabular}{|l|c|c|c|c|c|c|c|}
\hline & ANOVA & I.II & I.III & I.IV & II-II & II.IV & III.IV \\
\hline Height & 1.71 & 1.84 & 1.19 & 0.97 & 2.69 & 2.79 & 0.41 \\
\hline Mass & 3.26 & 0.06 & $3.82^{*}$ & 2.38 & $3.65^{*}$ & 2.21 & 1.91 \\
\hline BMI & 1.06 & 0.76 & 1.91 & 0.24 & 2.49 & 1.01 & 1.74 \\
\hline Waistline & 0.71 & 0.52 & 0.51 & 1.60 & 0.93 & 0.99 & 1.83 \\
\hline Hipline & 1.69 & 1.78 & 1.68 & 0.65 & 3.12 & 1.19 & 2.24 \\
\hline WHR & 1.27 & 1.24 & 1.07 & 1.31 & 2.08 & 2.52 & - \\
\hline Arm circumference & 0.63 & 0.57 & 1.46 & 0.13 & 1.88 & 0.46 & 1.58 \\
\hline Lower leg circumference & 0.82 & 0.13 & 1.97 & 0.61 & 2.02 & 0.71 & 1.50 \\
\hline Elbow base width & 1.75 & 2.07 & 0.38 & 1.10 & 2.11 & 3.15 & 0.52 \\
\hline Knee base width & 2.98 & 3.17 & 1.71 & $3.97^{*}$ & 1.01 & 0.56 & 1.54 \\
\hline Biceps skinfold & 2.07 & 2.92 & 2.93 & 2.22 & 0.38 & 0.86 & 1.14 \\
\hline Triceps skinfold & 3.24 & 2.31 & 2.15 & 1.15 & $4.02^{*}$ & $3.45^{*}$ & 1.23 \\
\hline Chest skinfold & 0.50 & 0.02 & 1.34 & 1.13 & 1.31 & 1.09 & 0.43 \\
\hline Elbow skinfold & 0.33 & 0.57 & 0.99 & 0.32 & 0.49 & 0.88 & 1.27 \\
\hline Shoulder blade skinfold & 0.51 & 0.67 & 1.17 & 0.28 & 1.69 & 0.42 & 1.41 \\
\hline Stomach skinfold & 0.51 & 1.41 & 0.11 & 1.32 & 1.08 & 0.17 & 0.98 \\
\hline Lower leg skinfold & 7.57 & $5.55 *$ & 2.30 & $\mathbf{5 . 9 3}$ & 2.43 & - & 2.55 \\
\hline Total of 3 folds & 0.83 & 0.84 & 1.63 & 0.12 & 2.28 & 0.96 & 1.55 \\
\hline F\% & 1.15 & 0.86 & 1.69 & 1.09 & 2.36 & 1.91 & 0.81 \\
\hline TA\% & 1.15 & 0.86 & 1.69 & 1.09 & 2.36 & 1.91 & 0.81 \\
\hline Fkg & 2.37 & 0.60 & 2.95 & 1.71 & 3.36 & 1.86 & 1.58 \\
\hline TAkg & 3.19 & 0.55 & $\mathbf{3 . 9 5} *$ & 2.57 & $\mathbf{3 . 3 6}$ & 1.88 & 1.89 \\
\hline
\end{tabular}

* statistically significant differences at a level of $p \leq 0.05$

In comparing the results obtained for female students of tourism and recreation with those for students of physical education, it was noted that the first group exhibited significantly lower body mass and a lower absolute value of lean body mass as compared to their peers. Furthermore, higher values were noted for skinfold measurements on the biceps and chest and for percentage of lean body mass. Although in most cases this group exhibited lower values for the morphological values in question, these differences were insignificant.

The next group was students of cosmetology, who in comparison to physical education majors had significantly broader knee bases and thicker skinfolds on their lower legs. No statistically significant differences were observed in the analysis of remaining features. However, they did exhibit slightly higher levels for body height and mass, BMI, lower leg circumference, elbow base width, skinfold on the triceps and absolute value of lean body mass. Nevertheless, with regard to the remaining features in question, students of cosmetology exhibited higher values for somatic features as compared to their peers in the remaining groups.

In comparing the results obtained for students from each subject group, it was determined that students of physiotherapy and tourism and recreation had significantly higher chest skinfold measurements and absolute body masses. However, the only significant difference between students of physical therapy and cosmetology was to be found in the triceps skinfold measurement. Furthermore, female students of tourism and recreation and cosmetology were not found to differ significantly from each other with regard to any of the features analyzed.

\section{Discussion}

The minor differences detected in the analysis of somatic features of female students contradict findings by other authors whose research focuses on connections between physique and educational profile. Cabryć et al. [12] and Pasiut [13], among others, have found female students to be better developed physically. These authors attribute this fact to the selection process. Criteria applied during examinations result in the selection of a group of physical education students with highly developed motor skills and higher levels for somatic features and developmental indexes, which translates into superior physical fitness as compared to other majors. It should be emphasized, however, that the female students we studied had not undergone an initial selection process due to the small number of candidates; this may also have influenced the results. Within the context of the Biała Podlaska student body as a whole, arguments were already being made a decade ago to the effect that the somatic features of first-year candidates for physical education, especially their high levels of obesity coupled with poorly developed muscular and skeletal structure, suggested that their sole motivation in studying was probably to obtain a degree from an institution of higher learning. This conclusion was dictated by the observation that the physique of students of physical education at this time deviated significantly from that of students of the same subject at other colleges or of people playing sports [5]. Mleczko and Januszewski [14] emphasize that at present, young people undertaking to study at AWF exhibit more somatic development than motor development. This is attributed, among other things, to the lower motor skill potential among the high school students recruited as candidates for the educational profile in question.

Authors of publications concerning connections between somatic features, physical fitness and success in various sports disciplines [15, 16, 17], argue that apart from the type of physique characteristic of a given discipline, the body composition and its proportion of fat to lean body mass is particularly important. At the same time, they emphasize that tissue component measurements are conditioned, among other things, by the character and duration of physical exertion, as well by the subject's age. Minor differences between groups were noted with regard to obesity levels and how fat is distributed, but this seems not to be connected with physical activity resulting from the study program. Female students of physical education attend at least 10 hours of classes involving physical activity each week, while students of other majors are required to take only 2 hours of such classes. However, it should be emphasized that the study was limited to first-year female students. In the course of studies for sports-related majors, the large number of practical exercises needs must influence somatic features [18]. Thus, it should be assumed that more marked differences among the groups in question would be noted in subsequent years, since physical exercise can influence energy levels and tissue composition. This dependency has also been pointed out by Yildiz et al. [19] in observations of students from Physical Education College in Aydin, Turkey.

The study also reveals a lack of differences between groups with regard to BMI and WHR indexes, both of which were normal for all of the groups involved in the study. It should be borne in mind, however, that the first of these two indexes is applied twofold in population studies. First, dietary status is determined, then overweightness and obesity levels are assessed. No reference is made to individual tissue elements, however. As can be seen from the results of screening studies [20] of average BMI, the index increases with the age of the subject, as does the percentage of subjects suffering from overweightness and obesity. The fact that female students with different majors exhibit similar BMI indexes confirms a low level of differentiation with regard to weight and height. It should be borne in mind, however, that this index does not provide any information concerning magnitudes of tissue elements.

The WHR index used in this study to determine distribution 
of fatty tissue is universally applied in recognizing central obesity [21, 22]. The model of fatty tissue distribution is strongly influenced by the level of physical activity and the sensitivity of fat cells in various parts of the body to active lipolytic factors during physical exertion [23, 24]. The index values obtained for all of the groups fell within the normal threshold and these values indicate gynoid obesity among the women in question.

The study did not confirm reports from other authors concerning analysis of connections between bodily structure and education profile. Thus, it should be concluded that a student's physique plays only a small role in their being selected to study physical education. The differences noted between the groups should rather be interpreted as owing to environmental differences in the lifestyles of the girls in question, rather than to recruitment procedures and, by extension, education profile.

\section{Acknowledgements}

The research accomplished within the framerork of research project of Faculty of Physical Education and Sport in Biała Podlaska The Josef Pilsudski University of Physical Education in Warsaw - DS.172 - financed by Ministry of Science and Higher Education.

\section{Literature}

1. Sporis G., Jukić I., Bok D., Vuleta D. Jr., Harasin D. (2011). Impact of body composition on performance in fitness tests among personnel of the Croatian navy. Collegium Antropologicum 2, 335-339.

2. Smolarczyk M., Wiśniewski A., Czajkowska A., Kęska A., Tkaczyk J., Milde K., et al. (2012). The physique and body composition of students studying physical education: a preliminary report. Pediatric Endocrinology, Diabetes and Metabolism 1, 27-32.

3. Vernillo G., Schena F., Berardelli C., Rosa G., Galvani C., Maggioni M., et al. (2013). Anthropometric characteristics of top-class Kenyan marathon runners. Journal of Sports Medicine and Physical Fitness 4, 403-408.

4. Mleczko E., Mirek W. (2009). The social structure transformation and inter-generational changeability of somatic and motor development in Cracovian students. Kinesiology 47, 37-42.

5. Wasiluk A., Saczuk J., Litwiniuk S. (2003). Selected parameters of body build of candidates for physical education studies in the Institute of Physical Education and Sports in Biała Podlaska. Physical Education and Sport 2, 239-253.

6. Central Statistical Office (2012). Statistical yearbook of the Republic of Poland. Warsaw. Retrieved 20.10.2013 from http://www.stat.gov.pl/cps/rde/xbcr/gus/RS_rocznik_statystyczny_rp_2012.pdf.

7. Buchta K., Lisicki T. (2011). Undergraduate studies in physical education in students' opinion. Polish Journal of Sport and Tourism 2, 146-159.

8. Martin R., Saller K. (1957). Lehrbuch der Anthropologie in systematischer Darstellung mit besonderer Berücksichtigung der anthropologischenm methoden. Stuttgart: Gustav Fisher Verlag.

9. World Health Organization (September 2006). Obesity and overweight. Fact Sheet. No 311. Geneva: WHO Press Office.

10. Slaughter M.H., Lohman T.G., Boileau R.A., Horswill C.A., Stillman R.J., van Loan M.D., et al. (1988). Skinfold equations for estimation of body fatness in children and youths. Human Biology 5, 709-723.
11. Bray G., Bouchard C. (Eds.) (2008). Handbook of obesity: clinical applications ( $3^{\text {rd }}$ edition). New York, USA: Informa Healthcare. Retrieved 20.10.2013 from http://www.pmc.ps/ pdf/Handbook\%20of\%20Obesity\%20Clinical\%20Applications,\%203rd\%20edition.pdf.

12. Cabrić M., Krakowiak H., Janczak R. (2003). Comparison of body constitution and body composition in female students in various fields of study. Polish Journal of Physiotherapy 3 , 272-276.

13. Pasiut U. (2012). Biological state of the students at the University School of Physical Education on the background of the whole of young adults studying in biggest state universities of Cracov. Kinesiology 60, 111-122.

14. Mleczko E., Januszewski J. (2009). Long-term trends of changes in physical and motor development observed among Cracovian students. Kinesiology 46, 65-79.

15. Starkowicz-Przybycień B. (2010). Body composition and somatotype of the top of Polish male karate contestants. Biology of Sport 3, 195-201.

16. Veale J.P., Pearce A.J., Buttifant D., Carlson J.S. (2010). Anthropometric profiling of elite junior and senior Australian football players. International Journal of Sports Physiology and Performance 4, 509-520.

17. Saczuk J., Wasiluk A. (2012). Dependence between body tissue composition and results achieved by weightlifters. Baltic Journal of Health and Physical Activity 1, 15-20.

18. Wasiluk A. (2011). The characteristics of changes in the physical development of female students from the Faculty of Physical Education in Biała Podlaska as affected by the size of the place of residence in a continuous study. Rocznik Naukowy AWFiS w Gdańsku 21, 44-51.

19. Yildiz Y., Karakaş S., Güneş H., Köse H. (2009). Reflection of sport awareness on body composition in students at the School of Physical Education and Sports. Trakya Üniversitesi Tıp Fakültesi Dergisi 3, 249-255.

20. Doak C., Wijnhoven T., Schokker D., Visscher T., Seidel J. (2012). Age standardization in mapping adult overweight and obesity trends in the WHO European Region. Obesity Reviews 2, 174-191.

21. Bamoshmoosh M., Massetti L., Aklan H., Al-Karewany M., Goshae H.A., Modesti P.A. (2013). Central obesity in Yemeni children: A population based cross-sectional study. World Journal of Cardiology 8, 295-304.

22. Kartheuser A.H., Leonard D.F., Penninckx F., Paterson H.M., Brandt D., Remue C., et al. (2013). Waist circumference and waist/hip ratio are better predictive risk factors for mortality and morbidity after colorectal surgery than body mass index and body surface area. Annals of Surgery 5, 722-730.

23. García-Unciti M., Izquierdo M., Idoate F., Gorostiaga E., Grijalba A., Ortega-Delgado F., et al. (2012). Weight-loss diet alone or combined with progressive resistance training induces changes in association between the cardiometabolic risk profile and abdominal fat depots. Annals of Nutrition and Metabolism 4, 296-304.

24. Strasser B., Arvandi M., Siebert U. (2012). Resistance training, visceral obesity and inflammatory response: a review of the evidence. Obesity Reviews 7, 578-591.

Submitted: October 30, 2013

Accepted:December 5, 2013 